\title{
DEVICES FOR LIQUIDATING SMALL CLAIMS IN DETROIT
}

\author{
Rolp NUGENT*
}

The problem of the small debtor has existed in all civilizations which have recognized private property rights. It antedates by many centuries the beginnings of instalment selling. But the current problem of the small debtor in the United States cannot be dissociated from the consequences of easy-payment merchandising. Debt is an essential by-product of an instalment sales contract. The growth in the number of such contracts during the post-war period has tended to increase the extent of the problem of the impecunious debtor, while the use by instalment merchants of powerful collection weapons has tended to increase its severity.

The city of Detroit has had more than its share of the problem of the small debtor. This accounts perhaps for the fact that the most elaborate and, we believe, the most significant experimentation with remedies has occurred in that city.

The collapse of business and finance in Detroit following the precipitate decline in automobile production between 1929 and 1932 has been so widely publicized that it needs little exposition here. Its effect was to wipe out most of the asset items on the balance sheets of Detroit's industrial wage-earners and to leave on the liability side of these ledgers deficiency judgments on foreclosed homes, building lots, and repossessed automobiles, and unpaid bills for goods and services which had been contracted in more prosperous days or accumulated during periods of unemployment.

Two other circumstances contributed to the severity of the problem. The first of these was the seasonal character of employment in Detroit. Not only the employes of the automobile industry itself but employes of those enterprises which supplied goods and services to automobile employes, felt the effect of the seasonal demand for automobiles. Even employes of public service companies, who usually enjoyed stable employment elsewhere, were subject to seasonal lay-offs following shut-downs in the automobile industry. The uncertainty of employment added to the seriousness of the small debt problem by making any promise of future payment unreliable, by . creating misunderstanding between debtor and creditor, and by penalizing the creditor who did not enforce repayment by whatever device was at hand while the debtor was still on the payroll.

\footnotetext{
-B.A., 1923, Amherst College. Director, Department of Remedial Loans, Russell Sage Foundation. Co-author of Regulation of the Small Loan Business, Russell Sage Foundation, 1935.
} 
The second circumstance was the severity of the Michigan garnishment law. By means of garnishment process, the creditor could attach 70 per cent of the debtor's wages if the debtor were single and 40 per cent if he were married, but not more than $\$ 30$ and not less than \$o of a married man's current bi-weekly wages was exempt. Because of the maximum exemption and the fact that many workers in Detroit got less than five months' work a year, as much as 50 or 60 per cent of a married wageearner's annual earnings might be taken by repeated garnishment. In periods of full-time work, the process tended to take all the surplus beyond living expenses which the debtor relied upon to carry him through lay-off periods.

Garnishment caused hardship to the debtor not only because it left him with an inadequate allowance to support his family, but also because it was extremely expensive and frequently led to his dismissal. The court charge for a judgment was $\$ 2.00$ and for a garnishment order, \$2.50. In addition, the debtor's employer might demand a show-cause order costing $\$ 1.00$, before recognizing the garnishment order. A new garnishment order had to be issued and a new show-cause order could be demanded before each succeeding pay check could be attached. The largest employer of labor in Detroit maintained a rule (to which frequent exception was made, however,) that employes whose wages were garnished should be immediately discharged. Although it was unusual for other employers to discharge for a single garnishment, many considered a second or third garnishment to be sufficient ground for dismissing an employe.

Pressure for the development of more adequate facilities for debt liquidation appears to have come not only from those seeking to protect employe-debtors, but also from groups of creditors and from employers. Many creditors who were unwilling to resort to garnishment found that the debtor's means of payment was pre-empted by other creditors who had no such compunction. Employers favored the avoidance of garnishment because they were annoyed by the bookkeeping costs incident to it.

\section{The Conciliation Division of the Detroit Common Pleas Court}

The first and by far the most important effort to facilitate the liquidation of small debts was made by the Common Pleas Court for the city of Detroit. In October, x932, by order of the presiding judge, a Conciliation Division was established within the court.

The purpose of the Conciliation Division, originally, was to attempt to settle without cost small claims. by indigent creditors. All creditors filing claims were required to agree to abide by the settlement. Attorneys were not permitted to file claims in the Division. The maximum amount of any claim was limited to $\$ 35$, but this could be increased to $\$ 100$, in the discretion of the presiding judge, if the claim was meritorious and the creditor indigent. Actions pending or actions in which judgment had been granted could be transferred to the Division by consent of both 
parties. The Division was authorized to arrange for partial payments by the debtor and to prohibit the issuance of any garnishment or attachment while the debtor complied with his agreement.

The Conciliation Division immediately began to receive and to arrange for periodic payments upon many claims by small landlords, boarding-house keepers, grocers, and individuals. The most frequent plaintiffs, however, were prevented from initiating actions in the Division because they could not meet the requirement of indigence. Since they could not use the facilities of the Division for initiating claims without cost, they preferred to rely upon the threat, and if necessary the execution, of garnishment orders to satisfy their judgments.

Judge Joseph A. Gillis, who has been in charge of the Conciliation Division since its inception, wrote of his efforts to arrange for partial payments on judgments as follows:

It was brought to my attention in several hundred instances that workingmen, who had just returned to work and had accumulated several debts which had been reduced to judgment, had every pay garnisheed. I then attempted, as an experiment, to bring plaintiffs and defendants together, requesting the plaintiffs to accept a certain sum of money out of the defendant's pay and to waive their rights of garnishment. I soon found that in order to do this it would be necessary for the court to collect the money and impound the file in the case so that garnishment would not issue. In the months of November, December, and January, I932-r933, several hundred agreements were entered into voluntarily, and it was noticed that in about 90 per cent of the cases defendants faithfully kept their word and made their payments, so that arrangements were satisfactory to the plaintiffs. However, in many instances, one plaintiff would refuse to stop garnishment proceedings, even though four other plaintiffs having judgments against the same defendant would agree, and many instances were found where defendants lost their positions because of a series of garnishments against them.

In coöperation with the Detroit Bar Association, Judge Gillis drafted a bill to extend the powers of the court to cover this situation. The bill, which applied only to the Detroit Court, became law in June, $1933 .{ }^{1}$ It provided (I) that motions for partial payments on judgments might be made by either party to the action, (2) that the Court should fix the amount of such payments, based upon the debtor's wages, after a hearing, (3) that payments were to be made to the Court, (4) that writs of garnishment in execution of the judgment should not be issued while the debtor made the agreed payments, and (5) that upon failure of the debtor to make such payments the order of the Court would be set aside and the creditor might proceed with garnishment.

Although this enactment did not mention the Conciliation Division, it was convenient for the Division to continue to handle motions for partial payments on judgments. The number of motions for partial payments on judgments increased rapidly and these motions soon became the predominant part of the business of the Division. By February I, I935, 22,500 claims had been entered in the Division and payments

${ }^{1}$ Mich. Pub. Acts 1933, No. 125. 
were being made through the Court on almost 5,000 current accounts. More than 90 per cent of current accounts represented partial payments on judgments.

The procedure of the Conciliation Division is simple and highly informal. A judgment-debtor who wishes to move for partial payments makes a certified statement showing the amount of the judgment, the name of his employer, the number of his dependents, and the amounts which he owes to other creditors. He is required to have his employer fill in a form showing the amounts recently paid to him in wages. The date of the hearing, which is always within ten days of the date of the motion, is set and the debtor is told to appear or to have some member of his immediate family appear for him. If the debtor has made motions for partial payments on several judgments, the Court sets the same time for all hearings. The motion is then entered on the docket and the creditor is notified of the motion and of the date of the hearing. Garnishment executions are immediately suspended.

Hearings are held four mornings a week and occasionally an additional hearing is held in the evening in order to accommodate debtors who could not otherwise appear. The creditor may appear in person, be represented by an attorney, mail a written consent, or permit the arrangement by failing to respond. At first most creditors appeared or were represented by attorneys. But more recently creditors appear or are represented only in unusual cases. The debtor appears in person or is represented by his wife. The Court calls first those cases in which attorneys have appeared.

Few of the usual rules of court procedure are adhered to. The Court attempts to ascertain the facts and determine the amount of periodic payments as quickly as possible. Many cases require only a few seconds to complete. In some cases, the creditor may challenge the debtor's statements; in others the Court asks questions of debtor or creditor. Involved cases are frequently postponed until those which can be handled quickly have been disposed of. Judge Gillis has a genius for getting to the heart of a debtor's difficulty in minimum time. Debtors and creditors are scolded and sympathized with impartially.

It is the policy of the Court to fix payments at approximately ro per cent of the debtor's usual wages. Payments may be fixed at a lower figure if there are several judgments, or at a somewhat higher amount if the debt was long delinquent and the debtor appeared to have been careless in meeting it. Some creditors objected strenuously at first to the payments fixed by the court. But these objections have gradually diminished, partly because of the satisfactory results of the partial-payment plan and partly because of the uselessness of their objections. If debtors object to the -payments, the Court asks, "How much would they get if they garnisheed?" The final admonition to all debtors is, "Don't miss your payments or they'll garnish your wages." Payments usually begin on the next payday following the hearing. The clerk of the Court makes a notation of each payment on the case record and the money is paid to the Court cashier. If a debtor is laid off, his payments are sus- 
pended and he is instructed to reinstate his motion as soon as he is re-employed. Part-time work frequently adds complications to the procedure, but the Court makes a practice of reducing payments if the debtor brings in a pay check for a very small sum.

In recent months, the Court has been handling from 25 to 60 cases at each session. The recording of payments has become a burdensome job and the staff of the Court has been increased to ro clerks. The routine work of preparing affidavits and explaining procedure to debtors is done by them. Fortunately, several speak Polish or Roumanian, and this is a great asset in dealing with debtors of these nationalities.

\section{The Personal Receivership Act}

Shortly after the enactment of the law which extended the powers of the Conciliation Division, a second bill was introduced in the Michigan legislature to facilitate the liquidation of small claims in municipal and justice courts in cities of more than 50,000 and less than 500,000 population. The bill was somewhat similar to a law which was enacted in Ohio several months earlier and apparently was inspired by this example. The bill was enacted in October, 1933, and the law is known as the Personal Receivership Act. ${ }^{2}$ This act provided that a debtor might assign his future wages to the clerk of the court. The clerk was then to return 60 per cent of the wages plus $\$ 1.00$ a week for each dependent child if the debtor was married and 40 per cent of the wages if the debtor was single. The debtor was required to file a certified statement listing his creditors and the amounts due to each. The amount withheld was then to be pro-rated among all creditors on the basis of the amount owed to each. The Court was to distribute money to creditors at least once every sixty days, or when the amount collected from a debtor reached $\$ 50$. The charge for this service was to be 50 cents for filing the statement of debts, and $5^{\circ}$ cents additional for each creditor listed.

Only one court in the environs of Detroit makes any considerable use of this device. This is the Municipal Court of Dearborn over which Judges Leo R. Schaefer and Lila M. Neuenfelt preside. By January, I935, this Court had received 90 applications from debtors and had 78 current cases. Its practice is to notify the employer that the debtor's wages have been assigned to the Court, as soon as the debtor files his statement. Employers' deductions, such as hospital payments or the repayment of sums advanced for relief, are usually made before the check is sent to the Court. No hearing is held unless a claim is contested and contests are rare. Many debtors are sent to the Court by creditors, particularly by grocers, and by employers. If the debtor wishes to have his case dismissed, a formal notice of dismissal is sent out. The reason for most dismissals is that the debtor becomes discouraged by the amount of his debts and the heavy drain which the assignment makes upon his income.

Approximately $\$ 50,000$ has been collected and disbursed by the Dearborn Municipal Court since October, I933. The number of debts listed by each debtor ranged

${ }^{2}$ Mich. Pub. Acts 1933, No. 184. 
from six to 23 , and the total amount owed from approximately $\$ 200$ to $\$ 2,231$. The largest total debt was reported by a policeman who owed 21 creditors. His case was later dismissed and he went through bankruptcy.

Clyde Fulton, a Justice of the Peace in Highland Park, has made much smaller use of the Personal Receivership Act. This Court handled but four personal receivership cases prior to January, I935.

The chief handicap to the extensive use of the Personal Receivership Act is its cost. The recording, pro-rating, and periodic disbursement of a large number of small items is exceedingly expensive and it is probable that small courts, which for budgetary reasons cannot expand their staff, will tend to discourage its use. The portion of each pay check taken by creditors, also, is large and if the debt is so great that the receivership must last for considerable time, debtors get discouraged by the heavy drain upon their incomes. A further handicap to the success of the Personal Receivership Act is the effect of its use upon the debtor's pride. Wage-earners are sensitive to the implication that it is necessary for a public official to handle their family finances for them. Most applicants for personal receivership came as the result of pressure by employers or creditors.

\section{Informal Procedure in a Hamtramck Justice Court}

A Justice Court in Hamtramck, a suburb of Detroit largely populated by Poles, has developed a third device for dealing with small claims. S. N. Grankowski, who took office as Justice of the Peace in July, 1934, considered using the Personal Receivership Act and finally rejected it because he believed that the debtor would be reluctant to meet its requirements and that expenses of administration would be prohibitive. He decided to handle partial payments informally as was done originally by the Conciliation Division of the Detroit Common Pleas Court. Since both the granting of judgments and the issuance of garnishment orders in execution of these judgments are in his hands, Justice Grankowski suspends garnishment in cases where the debtor asks to be permitted to make partial payments on a judgment. Informal hearings at which both debtor and creditor appear are held and the debtor gives a statement similar to that required by the Conciliation Division. The Court lacks power to do more than facilitate an agreement between the parties. Payments are determined by compromise and vary widely both in amount and in their relationship to the debtor's income, ranging generally between $\$$ r.0o and \$1o bi-weekly. Some payments are made to the Court and others are made directly to the creditor.

As in the Conciliation Division, agreements are suspended during lay-offs and the payments are reduced by the Court if the debtor gets a "short pay." Sometimes the debtor fails to keep his agreement and the creditor is given a writ of garnishment. Usually payments are subsequently reinstated on the motion of the debtor. Roughly 300 judgments a month are granted by the Hamtramck Justice Court and about one-fourth of the debtors apply for partial payments. The amounts are fre- 
quently small and repayment is generally more rapid than in the Conciliation Division. Little difficulty has been experienced in arranging settlements and there does not appear to be a need for further statutory authority. The personal relationship between most debtors and creditors in Hamtramck explains this situation in part. Creditors are generally small landlords, grocers, and butchers who have carried debtors while they were unemployed. Both debtors and creditors are usually Polish and have a relatively similar economic and social status.

Justice Grankowski believes that he would have more trouble in effecting agreements if automobile finance companies, instalment merchants, industrial banks, and small loan companies brought suits in his Court. Only one instalment merchant, a clothing company, brought any quantity of actions in the Hamtramck Justice Court in the past and it was always difficult to arrange settlements in these cases. The company has since failed.

\section{Michigan Merchants Credit Association}

A fourth device for debt liquidation was developed by the Michigan Merchants' Credit Association. The principal function of the Association was to supply credit information to instalment merchants, industrial banks, and automobile finance companies who were members of the Association. As a means of preventing ill-will among employers and customers, the Association attempted to avoid garnishment for delinquent accounts by developing a collection service. The Association receives from its members lists of defaulting customers with the names of their employers at the time of making the contract. The Association sends these names to employers who have agreed to coöperate, and the employer returns it, checking the names which are still on his payroll. Form letters are then sent to each defaulting debtor, frequently through the payroll clerk at the place of employment, pointing out the possibility of legal action and asking that the debtor come to the Association's office to discuss his difficulties. When the debtor calls, his situation is reviewed and he is urged if possible to agree to make reasonable payments on the account. In return for the promise of periodic payments, the Association promises that the creditor will not garnish the debtor's wages as long as payments are made. The Association serves only as a means of contact between the employer, the debtor, and the creditor in the negotiation of an agreement. Payments are made directly to the creditor.

The number of cases handled by the Association is small. It began its activities in August, 1934. By February 1, 1935, 445 cases had been turned over to it by its members and of these only $x 7 x$ cases resulted in agreements for future payments. The plan depends in large measure upon the willingness of employers to coöperate and the Association has gradually increased its list of coöperating employers. The number of cases handled and the number of cases in which agreements were effected have been increasing and it seems likely that this device will have a somewhat greater importance in the future. 


\section{Appraisal}

There can be little doubt that these four devices have made a material contribution to the amelioration of the problem of the small debtor in the Detroit area. They have served wage earners by avoiding harsh consequences of garnishment; they have served employers by relieving them of the bothersome bookkeeping involved in payroll executions and by improving the morale of their employes; and they have served creditors by facilitating the liquidation of delinquent accounts in an orderly manner. Such accomplishments benefit the whole business and social life of the community.

Two agencies-the Conciliation Division in Detroit and the Justice Court in Hamtramck-have handled considerable numbers of cases, and in both instances a large proportion of these cases have been completed successfully. That these agencies should have developed to their present extent in spite of the difficulties which seasonal employment has thrown in their way is ample evidence that there is a real need for their services.

The work of the Conciliation Division has a special significance with respect to instalment selling, because approximately half of the cases handled by the Division involve instalment purchase contracts. In the early experience of the Division, sharp practice among.plaintiffs who held judgments for instalment contracts was common. The Court, frequently discovered that constables had made fraudulent proof of summons and that debtors were not aware of suits against them until their wages were garnished. Tricks to secure judgment by default were not uncommon. Frequently defendants, upon whom service had been made, were led to believe that repossession cancelled the obligation, and deficiency judgments were then taken by default and garnishment orders executed. High attorney's fees occasionally were added to judgments for very small sums. Some creditors attempted to collect "locating charges," excessive court costs, and excessive interest charges on delinquent balances. Repossessions and sales of repossessed goods were frequently abusive.

These are but a few examples of a long list of questionable practices which had crept into the business of collecting delinquent accounts. Judge Gillis frequently called instalment houses or finance companies by telephone to object to certain practices and to suggest that they be discontinued. The Court's objections and admonishments extended not only to practices with which it had authority to deal, but to general collection methods and even to the conditions of sale, over which it had absolutely no jurisdiction. The willingness of the Court to dig into cases in order to expose anti-social practices has had a very salutary effect upon the instalment selling and financing business. The more flagrant abuses have been practically eliminated and others have been reduced materially. The Court recognizes thoroughly the limitations of its legal authority, but its power for improvement by means of moral suasion and the fear of publicity is great. Here, then, is an experiment with the regulation of instalment selling, which in spite of its limitations has had a fair degree of success. 
The same broad conception of its function is applied by the Division in giving advice to debtors. The Court frequently points out the usual cash price for articles which the debtor has bought on the instalment plan for a much higher price, and occasionally the Court's opinion on values is supplemented by an appraisal by a reputable merchant. Judge Gillis' unorthodox court-room technique is one of the real assets of the Division. His obvious personal interest in his cases and his freedom from procedural limitations has developed a relationship between the Court and the defendant which is rare except in certain European courts.

The experimentation with these agencies for debt liquidation in Detroit has more than local significance. Although the problem of the small debtor is unusually acute in Detroit, the need for similar facilities undoubtedly exists in other communities and perhaps in some degree throughout the nation. Without detracting from the credit which belongs to those who have labored to create these devices, it seems worth while to examine them critically in order to appraise their possible usefulness elsewhere. Like most other new devices, they have tended to adjust themselves to the necessities of each situation as it arose. There has been no experience that could be used as a guide, and little opportunity for advance planning or for careful considerations of public policy.

The pressure necessary to stimulate the development of these devices came, as we have already pointed out, from a combination of circumstances. These circumstances furnished not only the impetus for the initiation of these agencies, but also the conditions essential to their success. The mainspring of each of these devices is the willingness of the debtor to keep his promise to make regular payments, and it is unlikely that such promises would be kept generally if garnishment, in its present severe form, were not the penalty for default. As a recourse for the creditor after the debtor has failed to keep an agreement for reasonable partial payments, the severe garnishment privilege is perhaps justified. It should be remembered, however, that the garnishment law is state-wide and that many industrial communities in Michigan have developed no similar devices for partial payment. The existence of these Detroit agencies is in large measure dependent upon the continuation of a collection weapon which the legislatures of most states would reject as cruel. It follows also that similar devices would not be successful in communities which lacked similar penalties for default.

Although these debt-liquidating agencies have prevented garnishment in large numbers of cases, the number of such cases is still far exceeded by the number of garnishment executions. Even in Detroit, where the Conciliation Division handles approximately 1,000 motions a month, garnishments issued by the Common Pleas Court approximate 2,000 a month. Whether the garnishment law is not the essential element in ameliorating the small-debt problem in Detroit remains to be determined by a more careful study than we have been able to make.

Even the intensive effort given to partial payment cases fails in many instances 
to solve the debtor's longer-term problem. Both the Conciliation Division and the Hamtramck Justice Court tend to meet the emergencies of the small debtor by arranging for the liquidating of one or, at most, several debts which have been reduced to judgment. Payments on judgments are frequently made at the expense of payments on other delinquent accounts or current obligations. The Dearborn Court, where the number and amount of debts listed by individual debtors is large, appears, on the other hand, to deal with the debtor's whole problem. But the very breadth of its approach hampers its success. If the debtor lists all his debts, the amount is frequently overwhelming and the period over which he must make severe sacrifices to meet his obligations is so long that discouragement in many cases is inevitable. The debtor has a simple recourse from such discouragement. He may go into bankruptcy and avoid both his debts and the hardships involved in repaying them. The number of wage-earner bankruptcies in the Detroit area has increased rapidly.

It appears to the writer that all of these agencies lack one function which is essential to a broad approach to the problem of the small debtor. One of the characteristics of this problem is that the aggregate amount of the debt in many instances is out of line with the ability of the debtor to pay. Unless these debts can be reduced to an amount which can be paid over a reasonable period without too great a reduction in the debtor's standard of living, final default will only be postponed and efforts to facilitate repayment will favor one creditor at the eventual expense of other creditors. The job which needs to be done lies somewhere between the functions of the bankruptcy court and the functions of the small loan company and the industrial bank, which have perennially handled the refinancing and refunding operations of the family.

The problems to be met in accomplishing debt adjustment are great. To suggest that the Detroit agencies tackle this job is to express confidence in their ability to succeed in a larger field rather than to criticize the excellent work which they are doing in a more limited one. 